\title{
Modeling the role of highly oxidized multifunctional organic molecules for the growth of new particles over the boreal forest region
}

\author{
Emilie Öström $^{1,2}$, Zhou Putian $^{3}$, Guy Schurgers ${ }^{4}$, Mikhail Mishurov ${ }^{5}$, Niku Kivekäs ${ }^{6}$, Heikki Lihavainen ${ }^{6}$, \\ Mikael Ehn $^{3}$, Matti P. Rissanen ${ }^{3}$, Theo Kurtén ${ }^{7}$, Michael Boy ${ }^{3}$, Erik Swietlicki ${ }^{1}$, and Pontus Roldin ${ }^{1,3}$ \\ ${ }^{1}$ Division of Nuclear Physics, Lund University, Lund, P.O. Box 118, 221 00, Sweden \\ ${ }^{2}$ Centre for Environmental and Climate Research, Lund University, Lund, P.O. Box 118, 221 00, Sweden \\ ${ }^{3}$ Department of Physics, University of Helsinki, Helsinki, P.O. Box 64, 00014, Finland \\ ${ }^{4}$ Department of Geosciences and Natural Resource Management, University of Copenhagen, Copenhagen, 1350, Denmark \\ ${ }^{5}$ Department of Physical Geography and Ecosystem Science, Lund University, Lund, 223 62, Sweden \\ ${ }^{6}$ Finnish Meteorological Institute, Helsinki, P.O. Box 503, 00101, Finland \\ ${ }^{7}$ Department of Chemistry, University of Helsinki, Helsinki, P.O. Box 55, 00014, Finland
}

Correspondence to: Emilie Öström (emilie.ostrom@nuclear.lu.se)

Received: 10 October 2016 - Discussion started: 9 December 2016

Revised: 13 April 2017 - Accepted: 2 May 2017 - Published: 24 July 2017

\begin{abstract}
In this study, the processes behind observed new particle formation (NPF) events and subsequent organicdominated particle growth at the Pallas AtmosphereEcosystem Supersite in Northern Finland are explored with the one-dimensional column trajectory model ADCHEM. The modeled sub-micron particle mass is up to $\sim 75 \%$ composed of SOA formed from highly oxidized multifunctional organic molecules (HOMs) with low or extremely low volatility. In the model the newly formed particles with an initial diameter of $1.5 \mathrm{~nm}$ reach a diameter of $7 \mathrm{~nm}$ about $2 \mathrm{~h}$ earlier than what is typically observed at the station. This is an indication that the model tends to overestimate the initial particle growth. In contrast, the modeled particle growth to $\mathrm{CCN}$ size ranges ( $>50 \mathrm{~nm}$ in diameter) seems to be underestimated because the increase in the concentration of particles above $50 \mathrm{~nm}$ in diameter typically occurs several hours later compared to the observations. Due to the high fraction of HOMs in the modeled particles, the oxygen-to-carbon $(\mathrm{O}: \mathrm{C})$ atomic ratio of the SOA is nearly 1 . This unusually high $\mathrm{O}: \mathrm{C}$ and the discrepancy between the modeled and observed particle growth might be explained by the fact that the model does not consider any particle-phase reactions involving semi-volatile organic compounds with relatively low $\mathrm{O}: \mathrm{C}$. In the model simulations where condensation of low-
\end{abstract}

volatility and extremely low-volatility HOMs explain most of the SOA formation, the phase state of the SOA (assumed either liquid or amorphous solid) has an insignificant impact on the evolution of the particle number size distributions. However, the modeled particle growth rates are sensitive to the method used to estimate the vapor pressures of the HOMs. Future studies should evaluate how heterogeneous reactions involving semi-volatility HOMs and other less-oxidized organic compounds can influence the SOA composition- and size-dependent particle growth.

\section{Introduction}

Atmospheric particles affect climate by scattering and absorbing solar radiation and by influencing cloud formation and cloud optical properties. Their climate effect depends on both the size and composition of the particles and remains one of the largest uncertainties in global climate predictions (IPCC, 2013). Small-scale, process-based models are important tools for studying different mechanisms behind aerosol formation and growth. It is crucial to understand these processes in order to improve the predictability of nextgeneration climate and weather forecast models. 
In this study, the growth of biogenic secondary organic aerosols (BSOA) over the boreal forest in northern Europe is modeled and the results are compared to particle number size distribution measurements. New particle formation (NPF) events in boreal forests are frequent (Asmi et al., 2011; Kulmala et al., 2001; Tunved et al., 2003) and the newly formed particles can grow by condensation to the climate-relevant cloud condensation nuclei $(\mathrm{CCN})$ size range, which starts at a diameter of $\sim 50 \mathrm{~nm}$ (Kerminen et al., 2012). Komppula et al. (2005) found that particles in the boreal region in Northern Finland are typically able to activate into cloud droplets when they reach diameters larger than $80 \mathrm{~nm}$ (the minimum activation diameter varied from 50 to $128 \mathrm{~nm}$ ). In boreal forests, the growth of the particles is dominated by condensation of organic compounds formed from oxidation of biogenic volatile organic compounds (BVOCs) emitted by the vegetation (Kulmala et al., 2013). Studies have shown that NPF can provide a significant amount of CCN and thereby have a substantial climate impact (e.g., Jokinen et al., 2015; Kerminen et al., 2012; Merikanto et al., 2009; Scott et al., 2014; Spracklen et al., 2008).

The different ways to model the formation of BSOA found in the literature reflect the uncertainties of the formation mechanisms and also the often unknown properties of the condensable vapors. In many studies (e.g., Bergström et al., 2012; Farina et al., 2010; Fountoukis et al., 2014; Hodzic et al., 2009; Lane et al., 2008; Murphy et al., 2012) the vapors are assumed to be semi-volatile and in equilibrium with the (liquid, well-mixed) particles, making it possible to model formation of BSOA by simple gas-particle equilibrium partitioning (Pankow, 1994). In other studies (e.g., Scott et al., 2015; Spracklen et al., 2008; Tunved et al., 2010; Westervelt et al., 2013) the vapors are assumed to be nonvolatile and the irreversible particle growth is only limited by the collision rate between the vapor molecules and the particles. Recently, large-scale model studies (Jokinen et al., 2015; Langmann et al., 2014; Li et al., 2015; Riipinen et al., 2011; Yu, 2011) have included both mechanisms to be able to treat semi-volatile and nonvolatile vapors, which have yielded a better agreement between model results and observations. This hybrid SOA formation mechanism is an important step forward. However, in order to explicitly simulate the size-resolved condensational growth, models need to take into account how the chemical composition and curvature (Kelvin) effect vary with the size of the particles. Smog-chamber studies have often focused on the SOA formation from semi-volatile organic compounds (SVOCs). Recently the presence of highly oxidized multifunctional organic molecules (HOMs) in the gas phase has been shown in both lab and field studies (e.g., Ehn et al., 2014; Jokinen et al., 2015). Many HOMs can be low-volatility organic compounds (LVOCs; $10^{-4.5} \mu \mathrm{g} \mathrm{m}^{-3}<$ saturation concentration $\left(C^{*}\right)<10^{-0.5} \mathrm{\mu g} \mathrm{m}^{-3}$ ) or even extremely low-volatility organic compounds (ELVOCs; $C^{*}<10^{-4.5} \mu \mathrm{g} \mathrm{m}^{-3}$ ), while others are SVOCs $\left(10^{-0.5} \mu \mathrm{g} \mathrm{m}^{-3}<C^{*}<10^{2.5} \mu \mathrm{g} \mathrm{m}^{-3}\right)$
(Kurtén et al., 2016). The volatility distribution and aging of SOA in models will significantly affect the model results of SOA formation (Hermansson et al., 2014). Furthermore, the phase state of the particles can affect the dynamics of the growth (Zaveri et al., 2014). Traditionally, SOA particles are assumed to be well-mixed liquids; however, recent experimental studies indicate that they can be solid-like at ambient conditions (Renbaum-Wolff et al., 2013; Saukko et al., 2012; Vaden et al., 2011; Virtanen et al., 2010), which may influence their growth and lifetime (with respect to evaporation) in the atmosphere (Roldin et al., 2014).

In this study, we assume the organic vapors to condense dynamically on the Fuchs-corrected surface area of the particles. The two extremes of particle-phase state are tested; either the particles are assumed to be well-mixed liquid droplets or they are assumed to be solid-like without diffusion in the particle phase and with the gas-particle partitioning being controlled by the composition at the surface. Based on Ehn et al. (2014), a formation pathway of HOMs by the oxidation of $\alpha$-pinene, $\beta$-pinene and limonene is added. The aerosol dynamics are modeled along air-mass trajectories with an updated version of the Aerosol Dynamics, gas and particle phase CHEMistry and radiative transfer model (ADCHEM) (Roldin et al., 2011a). The modeled results are compared to particle number size distribution measurement at the subarctic station in Pallas, Northern Finland.

The aim is to evaluate the potential contribution of HOMs to the activation and growth of new particles over the boreal forest region. The model approach is described in Sect. 2, followed by results and discussion in Sect. 3 and conclusions in Sect. 4.

\section{Method}

ADCHEM was used to model the concentrations of gases and particles along air-mass trajectories ending at the Pallas Atmosphere-Ecosystem Supersite $\left(67.97^{\circ} \mathrm{N}, 24.12^{\circ} \mathrm{E}\right.$; 565 ma.s.l.) (Lohila et al., 2015) in Northern Finland. The emissions of different primary particulate and gaseous chemical species along the trajectories were derived from emission databases listed in Sect. 2.2. The modeled particle number size distributions for the Pallas site were compared to measured ones and the particle chemical composition to noncoincident aerosol mass spectrometer (AMS) measurements (Kivekäs et al., 2009; Jaatinen et al., 2014). The particle number size distributions measurements were conducted with a differential mobility particle sizer (DMPS) covering dry particle mobility range 7-500 nm (Komppula et al., 2003). The instrument was connected to a non-standard inlet with a cutoff diameter of approximately $5 \mu \mathrm{m}$ (Lohila et al., 2015). 


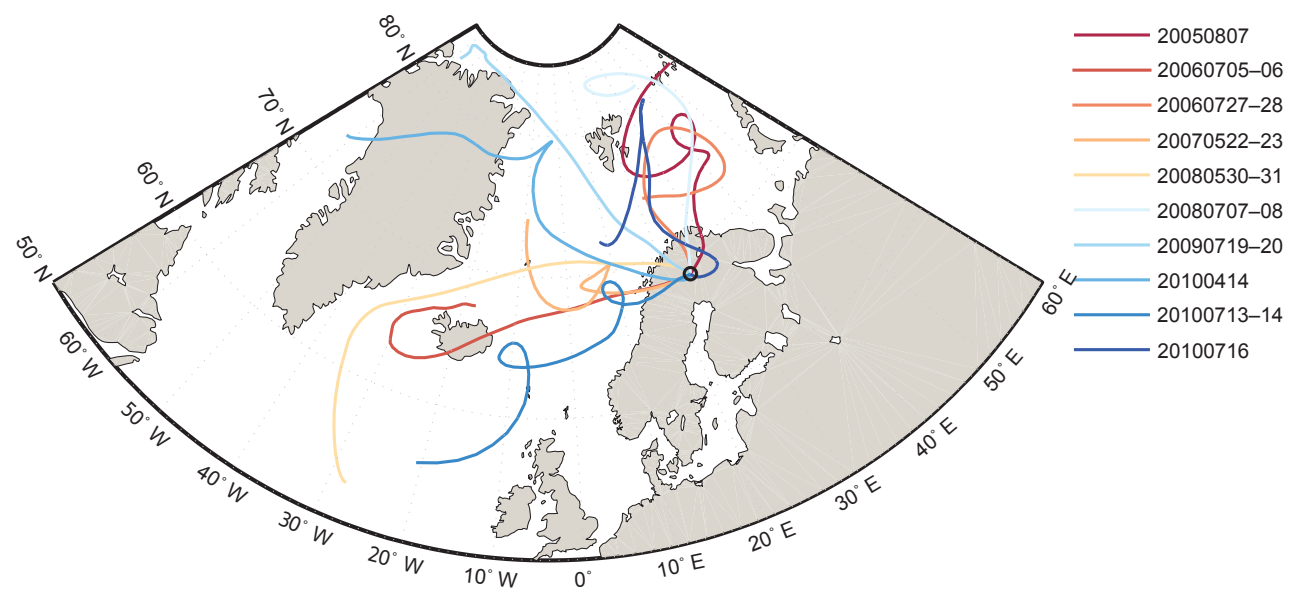

Figure 1. Mean HYSPLIT trajectories of each new particle formation event, all ending at Pallas. The trajectories start 7 days backward in time before they reach the measurement station.

\subsection{Air-mass trajectories}

Based on the particle number size distribution data measured at Pallas between 2005 and 2010, days with NPF events suitable for modeling SOA formation were selected for detailed analysis. This included days with strong new particle formation and subsequent growth of the new particle mode for at least $12 \mathrm{~h}$. This selection is roughly in line with type 1a events as defined by Dal Maso et al. (2005). The corresponding air-mass trajectories for these days were determined using the Hybrid Single Particle Lagrangian Integrated Trajectory Model (HYSPLIT) (Draxler and Rolph, 2013) with meteorological data from the Global Data Assimilation System (GDAS), downloaded from NOAA Air Resource Laboratory Real-time Environmental Application and Display sYstem (READY) (Rolph, 2016). The meteorological data resolution was linearly interpolated from $3 \mathrm{~h}$ to $1 \mathrm{~min}$ (the main model time step used in the simulations). The air-mass trajectories were calculated 7 days backward in time and ending at Pallas at 00:00, 03:00, 06:00, 09:00, 12:00, 15:00, 18:00 and 21:00 UTC. The analyzed cases were further decreased by including only those where all air-mass trajectories originated from clean marine environments. For each chosen new particle formation event the particle- and gas-phase evolution along the air-mass trajectories were modeled. In 7 out of the in total 10 selected cases, the growth of the newly formed particle mode could also be observed on the day after the start of the event. For these cases we ran ADCHEM for the day after the NPF event as well. In total the model was run along 136 air-mass trajectories. Figure 1 shows the mean trajectories for each new particle formation and growth event.

Information on land use along the trajectories was retrieved from the Global Land Cover Map for the Year 2000, GLC2000 database, European Commission Joint Research Centre (http://forobs.jrc.ec.europa.eu/products/glc2000/ products.php). Land-use categories were used to calculate the dry deposition of gases and particles.

\subsection{Emissions along the trajectory}

All emissions were added at each model time step to the model layer closest to surface, where they were assumed to be instantaneously well mixed within this layer.

\subsubsection{Gas emissions}

Anthropogenic emissions of $\mathrm{CO}, \mathrm{NH}_{3}$, non-methane volatile organic compounds (NMVOCs) (represented by 25 species; see Table $\mathrm{S} 1$ in Supplement), $\mathrm{NO}_{x}$ and $\mathrm{SO}_{2}$ were retrieved from the EMEP (European Monitoring and Evaluation Programme) database (EMEP/CEIP 2014, present state of emissions as used in EMEP models; http://www.ceip.at/ webdab_emepdatabase/emissions_emepmodels/). Dimethyl sulfide (DMS) emissions from marine plankton were also retrieved from EMEP. The modeled $\mathrm{SO}_{2}$ concentration in the surface layer $24 \mathrm{~h}$ upwind from Pallas was nudged towards the measured $\mathrm{SO}_{2}$ concentration at the station by increasing the emission of the gas when the modeled concentration was below the measured one. This applied to $\sim 50 \%$ of the studied trajectories, and for these cases the $\mathrm{SO}_{2}$ concentration was increased by a median factor of 1.8 . Nudging was done in order to get a more realistic nucleation rate since the modeled nucleation rate depends on the concentration of $\mathrm{H}_{2} \mathrm{SO}_{4}$ (Eqs. 2 and 3 in Sect. 2.3), which is formed by the reaction between $\mathrm{SO}_{2}$ and $\mathrm{OH}$. The median modeled (with nudging) and measured $\mathrm{SO}_{2}$ gas-phase concentrations during the NPF events are shown in Fig. S1b in Supplement.

Biogenic emissions ( $\alpha$-pinene, $\beta$-pinene, limonene, carene and isoprene) were estimated with the dynamic vegetation model LPJ-GUESS (Smith et al., 2014), which simulates the carbon and nitrogen cycling in terrestrial vegetation and 
which contains algorithms for isoprene (Arneth et al., 2007) and monoterpene (Schurgers et al., 2009a) production and emission by plants. Vegetation is represented with plant functional types (PFTs), and we applied 11 tree species common for northern Europe, one generic shrub type and one herbaceous type (Table S2), applying the bioclimatic limits as in Hickler et al. (2012) and Schurgers et al. (2009b). The parameterization of the PFTs and their isoprene and monoterpene characteristics follows Schurgers et al. (2009b), but the monoterpene emissions were split into three separate sets ( $\alpha$-pinene, $\beta$-pinene and limonene), as well as a generic set for all other monoterpenes (Table S2). The emissions of the last set were treated as if they were emissions of carene only. Carene was chosen to represent the generic set of monoterpenes because measurements on individual trees indicate that after $\alpha$-pinene, carene is dominating the emissions from boreal forest composed predominantly of Scots pine (e.g., Bäck et al., 2012; Smolander et al., 2014) or Norway spruce (Bourtsoukidis et al., 2014). The median fraction of the emitted monoterpenes along the air-mass trajectories that were not $\alpha$-pinene, $\beta$-pinene and limonene was $32 \%$.

LPJ-GUESS was run with the same meteorological data as used for determining the air-mass trajectories (GDAS; Rolph, 2016) using 3-hourly data for 2005-2010, preceded by a spinup of 500 years to establish the vegetation and soil pools. Photosynthesis production and emissions of isoprene and monoterpenes were computed at the 3-hourly resolution of the GDAS data using air temperature and radiation, resulting in diurnal variations of the plants' transpirational demand and water stress. The maximum photosynthetic capacity along with water and leaf nitrogen content varied daily, following the daily averages of GDAS data. Land use was prescribed at the level of 2005 following Ahlström et al. (2012).

\subsubsection{Primary particle emission}

Primary particle emissions of wind-generated marine aerosol as well as from ship and road traffic were included.

The primary marine aerosol production was estimated when the air-mass trajectories passed over ocean (determined by the land-use map from GLC2000) based on a parameterization from Mårtensson et al. (2003), with the use of wind-speed data from GDAS. The particles were assumed to be composed of $\mathrm{NaCl}$ and organic material based on the measurements and analysis of marine aerosol particles from Mace Head in Ireland during high biological activity (O'Dowd et al., 2004).

The emission of particles from ship and road traffic were estimated based on the $\mathrm{SO}_{2}$ emission from ship and $\mathrm{NO}_{x}$ emission from road traffic, respectively, both retrieved from EMEP. For the ship emissions, a conversion factor of $8.33 \times 10^{14}$ particles $\mathrm{g}\left(\mathrm{SO}_{2}\right)^{-1}$ (Beecken et al., 2015) was used while a conversion factor of $2 \times 10^{14}$ particles $\mathrm{g}\left(\mathrm{NO}_{2}\right)^{-1}$ (Kristensson et al., 2004) was used for the road traffic emis- sions. Kristensson et al. (2004) also provided parameters for the size distribution of the traffic emissions. The size distribution of the particles from the ship emissions was based on a study done by Jonsson et al. (2011). The smallest particles (diameter less than or equal to $40 \mathrm{~nm}$ ) were assumed to consist of $50 \% \mathrm{H}_{2} \mathrm{SO}_{4}$ and $50 \%$ organic material. Particles larger than $40 \mathrm{~nm}$ were assumed to have a core of soot (black carbon) coated with a $5 \mathrm{~nm}$ thick layer of equal molar fractions of $\mathrm{H}_{2} \mathrm{SO}_{4}$ and organic material.

\subsection{ADCHEM}

ADCHEM can be used as a two-, one- or zero-dimensional model to simulate the aging of an air mass along a trajectory (Hermansson et al., 2014; Roldin et al., 2011a, b). This section will focus on the modifications done to the model; for a detailed description of the model the reader is referred to Roldin et al. (2011a). In this study ADCHEM was used as a one-dimensional column model that solves the atmospheric diffusion equation in the vertical direction. The model included 20 vertical grid cells with a linear grid resolution of $100 \mathrm{~m}$, extending up to $2000 \mathrm{~m}$ a.g.l. The vertical diffusion coefficient $\left(K_{z}\right)$ was calculated based on a slightly modified Grisogono scheme (Jericevic et al., 2010) so that $K_{z}$ in Eq. (1) depends on the height above ground $(z)$, the friction velocity $\left(u_{*}\right)$ and the height of the atmospheric boundary layer $(H)$ :

$K_{z}=C u_{*} z \exp \left[-0.5(z /(0.21 H))^{2}\right], C=0.34$,

where $C$ is an empirical constant estimated from large eddy simulation (LES) data. The cloud base was always assumed to lie above the model domain, i.e., no in-cloud aerosol processing was considered. Low-level clouds might have been present $34 \%$ of the modeled times in the modeled domain on average, indicated by relative humidity $(\mathrm{RH})$ values above $98 \%$.

The gas-phase chemistry was solved using the Kinetic PreProcessor (KPP) (Damian et al., 2002) with selected organic and inorganic reactions from the Master Chemical Mechanism (MCM) version 3.3 (Jenkin et al., 1997; Saunders et al., 2003) and with spectral irradiance modeled with the radiative transfer model described in Roldin et al. (2011a). Table $\mathrm{S} 1$ lists the gas-phase precursors included in the chemistry module. The two monoterpenes $\alpha$-pinene and limonene that contain endocyclic double bonds were assumed to form HOMs initiated by their reaction with ozone. The HOM autoxidation mechanism was adopted from Ehn et al. (2014) and coupled to the MCMv3.3 mechanism. The HOM mechanism explicitly describes how the composition of the peroxy radicals $\left(\mathrm{RO}_{2}\right)$ formed from $\mathrm{O}_{3}$ oxidation of monoterpenes evolves as a result of sequential steps of intramolecular $\mathrm{H}$-shifts and $\mathrm{O}_{2}$ additions (autoxidation) (Crounse et al., 2013). In this work in total $9 \%$ of the first-generation $\alpha$ pinene $+\mathrm{O}_{3}$ oxidized products were assumed to undergo autoxidation, while for limonene this fraction was $22 \%$. These 
numbers give upper limits for the molar yield of HOM formation from ozonolysis of $\alpha$-pinene and limonene in our model. However, because of potential termination of the autoxidation mechanism with $\mathrm{NO}, \mathrm{HO}_{2}$ or $\mathrm{RO}_{2}$ already after one or two $\mathrm{H}$-shifts plus $\mathrm{O}_{2}$ additions, not all autoxidation products become HOMs $(\mathrm{O}: \mathrm{C} \geq 0.7)$. For conditions with low NO concentrations (as was generally the case for the simulations in this work) the modeled HOM molar yield of formation was close to the measured molar yields of $\sim 7 \%$ (for $\alpha$-pinene) and $\sim 17 \%$ (limonene) in the Jülich Plant Atmosphere Chamber (JPAC) (Ehn et al., 2014). These HOM yields are substantially higher than what was reported from flow tube experiments by Jokinen et al. (2015). One possible explanation to the different yields between these two studies is that the residence time in JPAC was substantially longer than in the flow tube. With longer residence time the autoxidation is allowed to run closer to completion, and for limonene specifically there is potential to react twice with ozone. Thus, the yields reported by Ehn et al. (2014) most likely better resemble the HOM yields at low NO conditions in the atmosphere.

For $\beta$-pinene ozonolysis the autoxidation channel is minor (Ehn et al., 2014) and was not considered in the model. According to Ehn et al. (2014) and Jokinen et al. (2015) products from $\mathrm{OH}$ oxidation of $\alpha$-pinene, limonene and $\beta$ pinene can also undergo autoxidation that leads to formation of HOMs. Jokinen et al. (2015) estimated that the molar yields of formation of HOMs from $\mathrm{OH}$ oxidation of $\alpha$ pinene, limonene and $\beta$-pinene are 13, 27 and $17 \%$ of the molar yield of HOM formation from $\alpha$-pinene $+\mathrm{O}_{3}$ reactions, respectively. Based on these results together with the molar yield of HOM formation from $\alpha$-pinene ozonolysis from Ehn et al. (2014) we estimated and used an upper limit molar yield of HOM formation from $\mathrm{OH}$ oxidation of $\alpha$ pinene, limonene and $\beta$-pinene of $1,2.5$ and $1.5 \%$, respectively. Figure S2 shows the modeled median gas-phase concentration of the HOMs during all modeled NPF events using different methods to estimate their vapor pressures (described below).

The aerosol dynamics module in ADCHEM considers new particle formation, Brownian coagulation, dry and wet deposition and condensation/evaporation. The changes in the particle number size distribution due to condensation, evaporation or coagulation were modeled using a full-stationary size grid (Jacobson, 2005) consisting of 100 size bins between $1.5 \mathrm{~nm}$ and $2.5 \mu \mathrm{m}$ in dry diameter.

The nucleation rate $\left(J_{1.5}\right)$ was assumed to be a function of the concentration of sulfuric acid and a first-generation oxidation product of the included monoterpenes denoted $\mathrm{ELVOC}_{\text {nucl }}$, formed with a molar yield of $10^{-5}$ for each monoterpene that reacted with $\mathrm{OH}$ (see Eq. 2). The low molar yield was chosen in order to prevent ELVOC $_{\text {nucl }}$ to have a substantial contribution to the modeled particle growth. This parameterization was recommended by Roldin et al. (2015), based on model simulations of NPF experiments with real plant emissions in JPAC. First-generation oxidation products from reactions with $\mathrm{O}_{3}$ were not included in $\mathrm{ELVOC}_{\text {nucl }}$ since these tend to give too many new particles during the night (Roldin et al., 2015).

$J_{1.5}=K_{1}\left[\mathrm{H}_{2} \mathrm{SO}_{4}\right]\left[\mathrm{ELVOC}_{\text {nucl }}\right]$,

where $K_{1}=2 \times 10^{-11} \mathrm{~cm}^{3} \mathrm{~s}^{-1}$.

This value of $K_{1}$ was chosen in order for the model to give the approximately correct total particle number concentration if averaged over all model simulations. $K_{1}$ was kept constant for all modeled nucleation events.

As an alternative to Eq. (2) the model was also run with kinetic $\mathrm{H}_{2} \mathrm{SO}_{4}$ nucleation:

$J_{1.5}=K_{2}\left[\mathrm{H}_{2} \mathrm{SO}_{4}\right]\left[\mathrm{H}_{2} \mathrm{SO}_{4}\right]$,

where $K_{2}=2 \times 10^{-14} \mathrm{~cm}^{3} \mathrm{~s}^{-1}$. In all model scenarios, the nucleation rate was determined by Eq. (2) if not otherwise noted.

Organic compounds with a pure liquid saturation vapor pressure $\left(p_{0}\right)$ less than $0.01 \mathrm{~Pa}$ were included in the condensation mechanism, where $p_{0}$ was estimated with the group contribution method by Nannoolal et al. (2008) using the UManSysProp online system (Topping et al., 2016). The $p_{0}$ of the HOMs were estimated with the group contribution method SIMPOL (Pankow and Asher, 2008). The Nannoolal et al. (2008) method was not used for the HOMs because it was shown to produce unrealistic estimates of vapor pressures for multifunctional HOMs containing hydroperoxide or peroxy acid groups (Kurtén et al., 2016). According to Kurtén et al. (2016) the SIMPOL method seems to be more robust and shows better agreement with the pure liquid vapor pressures of HOMs calculated with the detailed quantum-chemistry-based continuum solvent model COSMO-RS (Conductor-like Screening Model for Real Solvents) (Eckert and Klamt, 2002) than the Nannoolal method. The SIMPOL method does, however, give substantially lower vapor pressures than COSMO-RS. Thus, a sensitivity test was done where the vapor pressures of the HOMs calculated with SIMPOL were corrected based on the difference between the SIMPOL and COSMO-RS HOM vapor pressures reported by Kurtén et al. (2016) (Fig. S3). This yielded a correction factor of $10^{2.8 \times \mathrm{O}: \mathrm{C}-0.1}$, where $\mathrm{O}: \mathrm{C}$ is the oxygen-to-carbon ratio of the HOM monomers. For the HOM dimers we used a fixed correction factor of $10^{4}$.

The HOMs are probably very reactive in the particle phase and could therefore possibly be considered to be effectively nonvolatile despite their surprisingly high pure liquid saturation vapor pressures (Kurtén et al., 2016; Zhang et al., 2015). We evaluated the potential impact of irreversible reactive uptake of HOMs by performing simulations where the $p_{0}$ for the HOMs were set to zero, i.e., assuming that because of rapid irreversible reactions at the particle surface the HOM uptake is only limited by the collision rate between the HOMs and the particles. 
ADCHEM includes a detailed particle-phase chemistry module, adopted from the Aerosol Dynamics gas- and particle-phase chemistry model for laboratory CHAMber studies (ADCHAM) (Roldin et al., 2014). This module is used to calculate the particle equilibrium water content, the particle acidity, nitric acid and hydrochloric acid equilibrium vapor pressures for each particle size bin and the non-ideal interactions between organic compounds, water and inorganic ions using the activity coefficient model AIOMFAC (Zuend et al., 2008, 2011). In this work, we did not simulate the specific interactions between the organic and inorganic compounds but assumed a complete phase separation of the inorganic and organic particle phase. Topping et al. (2013a) concluded that the uncertainties in modeled SOA formation are far greater because of uncertainties in the organic compound pure liquid saturation vapor pressures than the omission of phase separation between organic and inorganic compounds. In line with this, we have previously shown that while the modeled SOA formation during $\alpha$-pinene ozonolysis experiments is relatively sensitive to the choice of pure liquid saturation vapor estimation method, it is relative insensitive to the omission of non-ideal interactions between the condensable organic compounds and between the organic compounds and ammonium (Roldin et al., 2014). In Kurtén et al. (2016) we computed the activity coefficients of 16 different HOM in a water-insoluble organic matter phase using the COSMOTherm software (Eckert and Klamt, 2014) and found that the activity coefficients varied between 0.59 and 2.01. Thus, in this work we did not simulate the specific interactions between the organic and inorganic compounds but assumed a complete phase separation of the inorganic and organic particle phase. We used AIOMFAC to calculate the equilibrium water content in the inorganic particle phase and the individual compound activity coefficients. The organic compound activity coefficients in the organic particle phase were assumed to be unity (ideal solution). The equilibrium vapor pressures of the organic compounds over the particle surface were derived from $p_{0}$ using Raoult's law and correcting for the Kelvin effect, using a surface tension of $0.05 \mathrm{~N} \mathrm{~m}^{-1}$ (Riipinen et al., 2010). The condensation, dissolution and evaporation of $\mathrm{NH}_{3}$ and $\mathrm{HNO}_{3}$ were calculated using the non-equilibrium growth scheme from Jacobson (2005). $\mathrm{H}_{2} \mathrm{SO}_{4}$ was treated as a nonvolatile compound, with irreversible condensation.

ADCHEM can be combined with a kinetic multilayer model for particles (Roldin et al., 2014) where each particle consists of a surface bulk layer and several bulk layers. In this study, the particles were either treated as liquid-like with no mass-transport limitations between the layers or as solidlike with no diffusion in the particle-phase. In the base-case simulations all particulate material except the core of the particles formed from soot particles were treated as liquid-like. The solid-like particles were represented with three layers (a monolayer thick surface layer of $0.7 \mathrm{~nm}$ and two bulk layers).
When the particles grow by condensation, material is moved from the surface layer into the first bulk layer.

\subsection{Initial conditions}

The initial particle size distribution was assumed to be a typical distribution found in clean maritime air (Seinfeld and Pandis, 2006) where $90 \%$ of the dry particle molar volume had the same chemical composition as the primary marine aerosols in Sect. 2.2.2 and the remaining dry volume consisted of ammonium sulfate.

The initial gas concentrations of $\mathrm{NO}_{x}, \mathrm{SO}_{2}, \mathrm{O}_{3}$ and $\mathrm{CO}$ were retrieved from MACC (Monitoring Atmospheric Composition and Climate) reanalysis dataset (Inness et al., 2013) archived in the ECMWF data server.

\subsection{Sensitivity tests}

Sensitivity tests were done to investigate the impact of the selected NPF mechanism (Eqs. 2 or 3) and how the growth of the particles was affected by the volatility of the HOMs and the SOA phase state of the particles. Table 1 lists the properties of the base-case simulation together with those of the sensitivity tests.

\section{Results and discussion}

This section presents the median characteristics of the modeled particle number concentration compared to the measured concentrations at Pallas. The results from the sensitivity tests of the model mentioned in Sect. 2.5 will also be presented. First, however, model results from a typical day of observed new particle formation event are discussed.

Figure 2 shows the modeled (base-case simulation) and measured particle number size distribution at Pallas on 5 July 2006. At the beginning of the new particle formation event, around 09:00 UTC (11:00 local standard time), almost $90 \%$ of the modeled particle volume in the nucleation mode consists of HOMs, the remaining volume largely consists of organic oxidation products from the MCMv3.3 chemistry scheme and sulfate (Fig. S4a). Nine hours later that day (Fig. S4b) the particles originating from the NPF event form a new Aitken mode with a geometric mean diameter of $\sim 50 \mathrm{~nm}$, according to both the model and the observations (Fig. 2). The volume fraction of VOC products from MCMv3.3 in the particle phase is now slightly larger than at 09:00 UTC (Fig. S4). This is partly because the Kelvin effect becomes insignificant when the particles have reached $\sim 50 \mathrm{~nm}$ in diameter, which allows more SVOCs to dissolve in the organic aerosol particles.

\section{Median particle number size distribution}

In Fig. 3a-d the observed and modeled (base-case scenario) median particle number size distributions for all chosen tra- 
Table 1. Different assumptions for the different model scenarios tested in this study.

\begin{tabular}{llll}
\hline Model scenario & Phase state & HOM vapor pressure method & Nucleation rate $\left(\mathrm{cm}^{3} \mathrm{~s}^{-1}\right)$ \\
\hline liq-SIM HOM (base case) & liquid & SIMPOL & $J_{1.5}=2 \times 10^{-11}\left[\mathrm{H}_{2} \mathrm{SO}_{4}\right]\left[\mathrm{ELVOC}_{\text {nucl }}\right]$ \\
\hline liq-NV HOM & liquid & nonvolatile & $J_{1.5}=2 \times 10^{-11}\left[\mathrm{H}_{2} \mathrm{SO}_{4}\right]\left[\mathrm{ELVOC}_{\text {nucl }}\right]$ \\
\hline liq-COSMO HOM & liquid & SIMPOL, corrected with COSMO-RS & $J_{1.5}=2 \times 10^{-11}\left[\mathrm{H}_{2} \mathrm{SO}_{4}\right]\left[\mathrm{ELVOC}_{\text {nucl }}\right]$ \\
\hline solid-NV HOM & solid & nonvolatile & $J_{1.5}=2 \times 10^{-11}\left[\mathrm{H}_{2} \mathrm{SO}_{4}\right]\left[\mathrm{ELVOC}_{\text {nucl }}\right]$ \\
\hline solid-SIM HOM & solid & SIMPOL & $J_{1.5}=2 \times 10^{-11}\left[\mathrm{H}_{2} \mathrm{SO}_{4}\right]\left[\mathrm{ELVOC}_{\text {nucl }}\right]$ \\
\hline liq-no HOM & liquid & no HOMs included & $J_{1.5}=2 \times 10^{-11}\left[\mathrm{H}_{2} \mathrm{SO}_{4}\right]\left[\mathrm{ELVOC}_{\text {nucl }}\right]$ \\
\hline liq-kin nucl & liquid & nonvolatile & $J_{1.5}=2 \times 10^{-14}\left[\mathrm{H}_{2} \mathrm{SO}_{4}\right]\left[\mathrm{H}_{2} \mathrm{SO}_{4}\right]$ \\
\hline
\end{tabular}

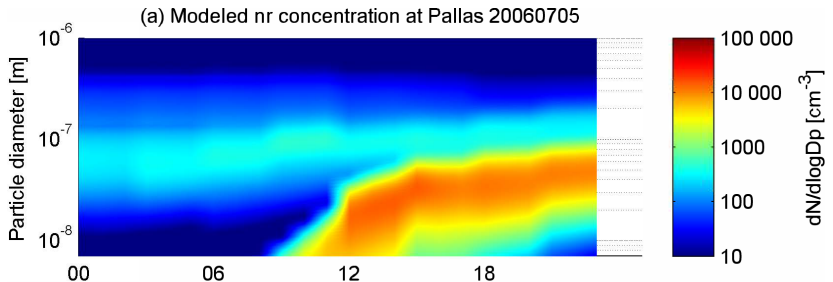

(b) Measured $\mathrm{nr}$ concentration at Pallas 20060705

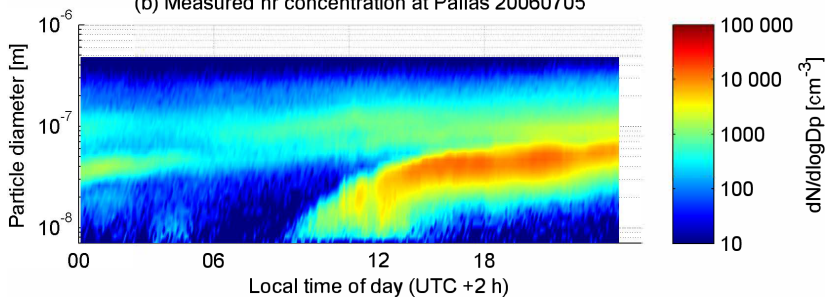

Figure 2. (a) Modeled and (b) measured number size distribution at Pallas, 5 July 2006.

jectories are presented together with their respective 25 and 75 percentiles. The newly formed particles reach the DMPS detection limit size of $7 \mathrm{~nm}$ in diameter around noon local time (10:00 UTC) and have by early morning the day after produced particles around $80 \mathrm{~nm}$, large enough to be able to act as CCN. From Fig. 3c-d it is clear that the model underestimate the concentration and geometric mean diameter (GMD) of the Aitken-mode particles originated from the NPF event the day before. For example, at midnight (Fig. 3c) the modeled median GMD of the complete size distribution is $30.8 \mathrm{~nm}$ and the total particle concentration $1820 \mathrm{~cm}^{-3}$, while in the observations it is $47.5 \mathrm{~nm}$ and $2630 \mathrm{~cm}^{-3}$.

While the median GMD and the concentration of the growing particles the day after the NPF events are underestimated, the model overpredicts the total number of particles larger than $7 \mathrm{~nm}$ in diameter $\left(N_{7}\right)$ at the beginning of the NPF (Fig. 4a).

This might be caused by a too-fast initial growth of the newly formed particles $(1.5-7 \mathrm{~nm}$ in diameter) or that the on-
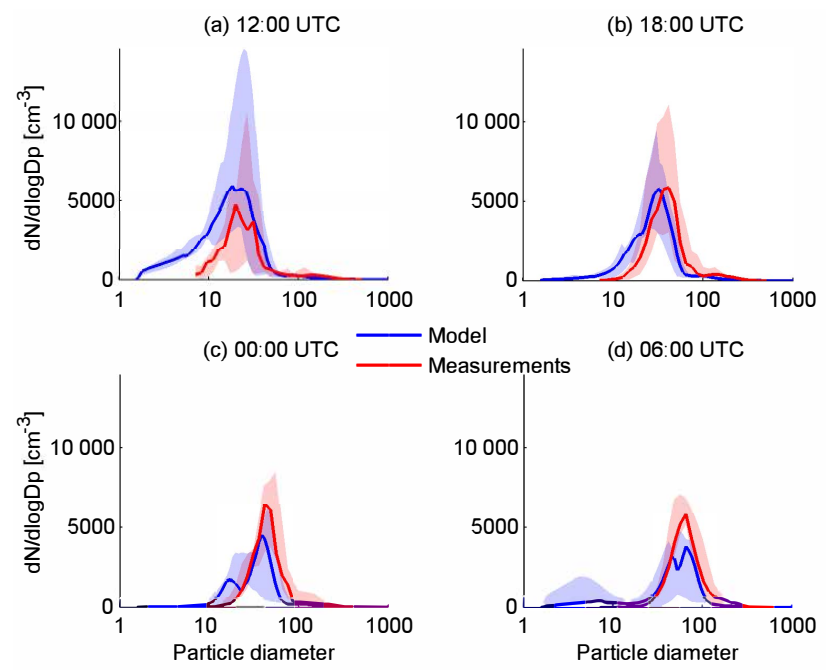

(d) 06:00 UTC

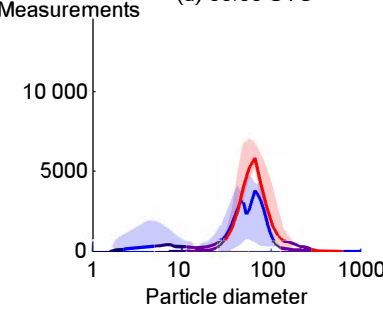

Figure 3. The modeled particles are assumed to be liquid and the vapor pressures of the HOMs are estimated with SIMPOL. Measured (red lines) and modeled (blue lines) median number size distributions at (a) 12:00 and (b) 18:00 UTC the day of the new particle formation event and at (c) 00:00 and (d) 06:00 UTC the following day. The shaded areas are the values that fall between the 25 th and 75th percentiles.

set of the NPF event happens about $2 \mathrm{~h}$ too early in the model. Two sensitivity tests were done to investigate the influence of the vapor pressures of the HOMs on the size- and timedependent particle growth. When the HOMs were assumed to be nonvolatile the trends in the modeled $N_{7}$ was very similar to the base-case scenario (Fig. 4b). Thus, when SIMPOL was used to predict the vapor pressures, most HOMs were effectively nonvolatile and could activate and grow the particles already at $1.5 \mathrm{~nm}$ in diameter. However, the median results from the simulation where the vapor pressures of the HOMs were corrected based on COSMO-RS, which resulted in higher vapor pressures of the HOMs, better predicted the timing of the new particles growth past the lower diameter detection limit of the DMPS system (Fig. 4c). When the 

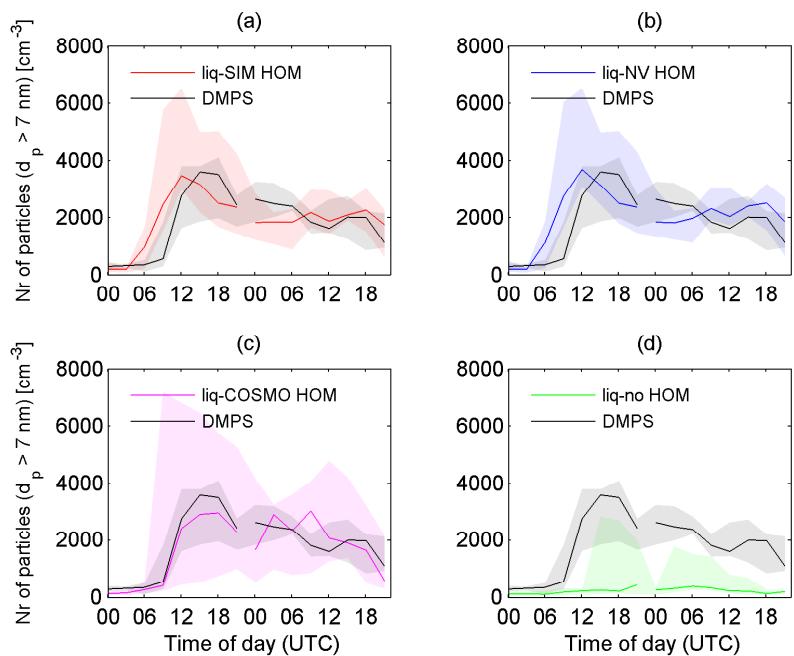

Figure 4. Median number of particles above $7 \mathrm{~nm}$ of all chosen NPF events at Pallas (from midnight on the day of the event to the evening the day after the start of the event) together with the 25 and 75 percentiles (shaded areas). The black lines are the median DMPS data from Pallas. The colored lines in $(\mathbf{a}-\mathbf{c})$ are the modeled median number of particles above $7 \mathrm{~nm}$, using different methods to estimate the vapor pressures of the HOMs (see Table 1). In (d), HOMs are excluded.

HOM formation was excluded, the modeled NPF had only a minor influence on $N_{7}$ (Fig. 4d) because most of the newly formed particles were not able to grow to observable sizes (Fig. S5). Thus, in more polluted environments where the autoxidation is terminated by $\mathrm{RO}_{2}+\mathrm{RO}_{2}$ or $\mathrm{RO}_{2}+\mathrm{NO}$ reactions before the oxidation products become $\mathrm{HOM}$, the particle growth may be suppressed.

The concentration of particles larger than $50 \mathrm{~nm}$ in diameter $\left(N_{50}\right)$ during the evening and the day after the NPF event in all four model simulations mentioned above (liqSIM HOM, liq-NV HOM, liq-COSMO HOM and liq-no HOM) are smaller than the observed $N_{50}$ (Fig. 5a-d). Especially during the evening and the day after the NPF events the model underestimated $N_{50}$. This is the case even if we consider that the HOMs are nonvolatile (Fig. 5b). Most likely this is because the model underestimates the growth of the particles larger than $20 \mathrm{~nm}$ in diameter. Similar results for the number concentration of particles larger than 30 and $80 \mathrm{~nm}$ in diameter can be found in Figs. S6-S7.

Figure 6 shows the modeled median vertical concentration profiles of $N_{7}$ and $N_{50}$ at the Pallas field station at 12:00 UTC the days of the NPF events and at 12:00 UTC the days after the NPF events. $N_{7}$ and $N_{50}$ are elevated in the whole boundary layer to an altitude of $\sim 800 \mathrm{~m}$ because of the previous day NPF events. Above the typical maximum boundary layer height of $\sim 800 \mathrm{~m} N_{7}$ decreases steeply from $>1000$ to $<10 \mathrm{~cm}^{-3}$ above $1600 \mathrm{~m}$. Thus, according to these model results NPF events in the sub-Arctic forest region can be
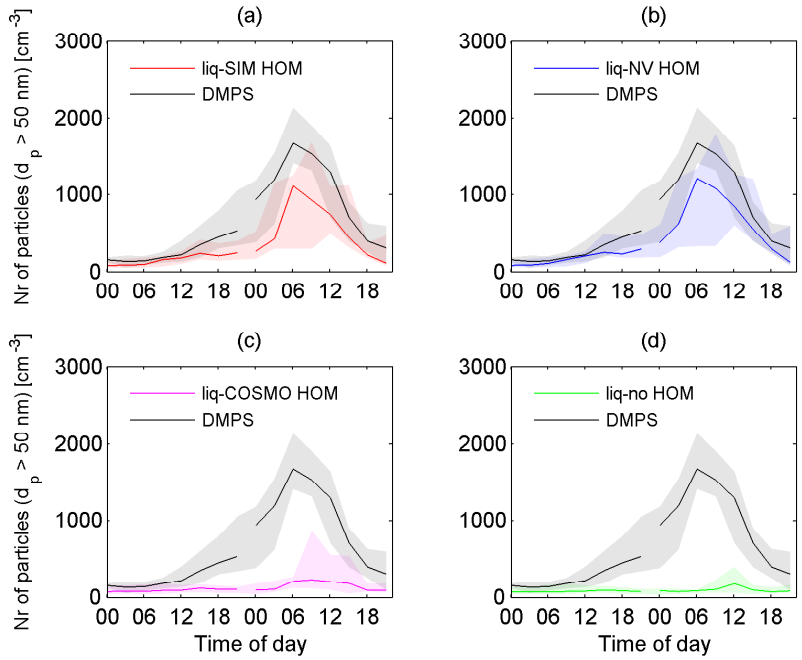

Figure 5. Median number of particles above $50 \mathrm{~nm}$ of all chosen NPF events at Pallas (from midnight on the day of the event to the evening the day after the start of the event) together with the 25 and 75 percentiles (shaded areas). The black lines are the median DMPS data from Pallas. The colored lines in $(\mathbf{a}-\mathbf{c})$ are the modeled median number of particles above $50 \mathrm{~nm}$, using different methods to estimate the vapor pressures of the HOMs (see Table 1). In (d), HOMs are excluded.

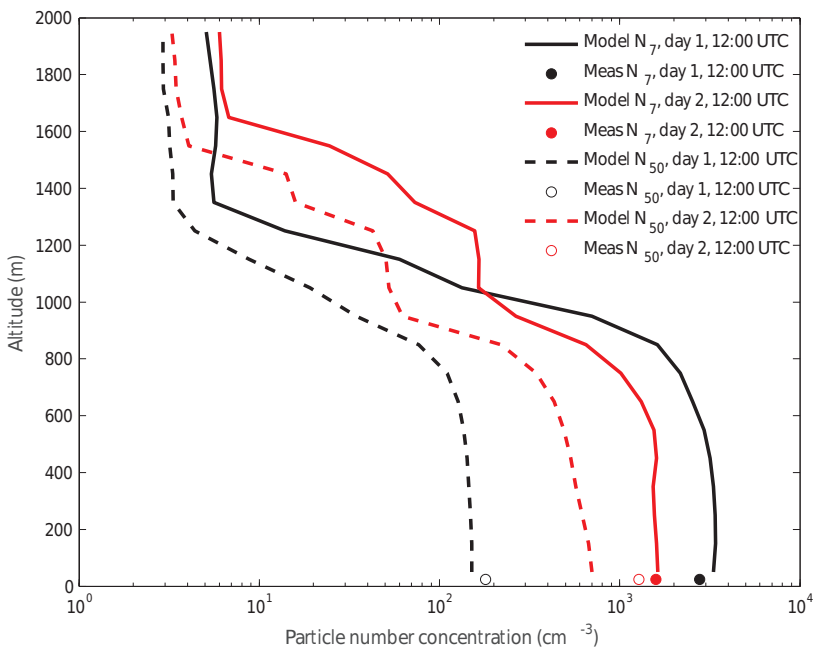

Figure 6. Modeled median vertical profiles of the particle number concentrations of particles larger than $>7 \mathrm{~nm}$ in diameter $\left(N_{7}\right)$ and $>50 \mathrm{~nm}$ in diameter $\left(N_{50}\right)$, respectively. Model results are shown both from the first day during the NPF events at 12:00 UTC and the second day after the NPF events at 12:00 UTC. Shown are also the observed median particle number concentrations at the surface.

an important source of $\mathrm{CCN}$ in the whole planetary boundary layer. Further, the observed $N_{7}$ and $N_{50}$ at the ground can give reasonable accurate estimates of $N_{7}$ and $N_{50}$ in the whole boundary layer but do not reflect the concentrations 


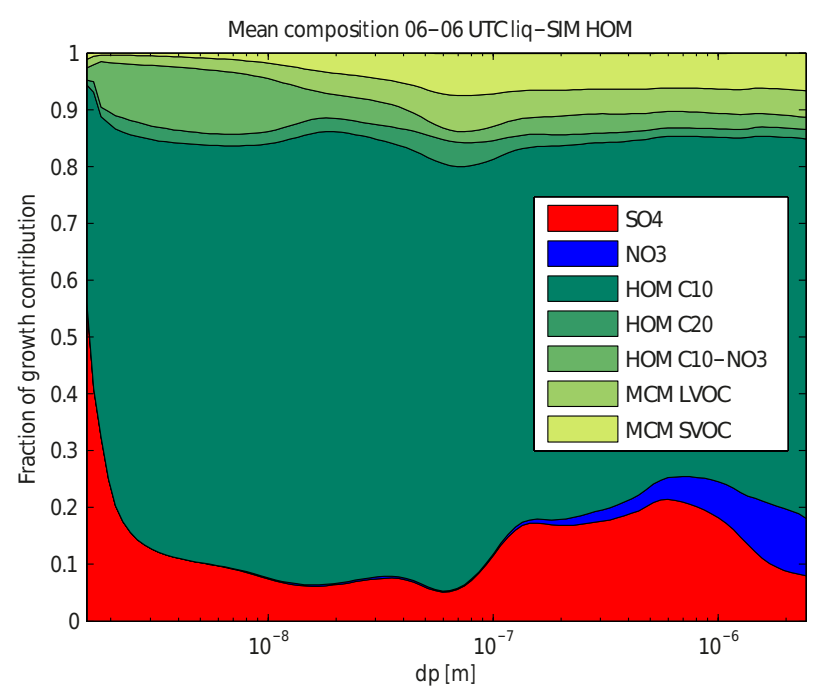

Figure 7. Mean mass fractions of each compound type that contributes to the growth of the particles during all chosen new particle formation events from the base-case simulations (from 06:00 UTC the morning of the event to 06:00 UTC the following day).

above the boundary layer either during the NPF events or the day after the events.

Figure 7 shows the mean mass fraction of each compound type that contributes to the growth during all chosen NPF events, from roughly the start time of the events (06:00 UTC) until the morning the next day (06:00 UTC). The growth of the particles is dominated by HOMs; the base-case simulation (Fig. 7) and the simulation with nonvolatile HOMs (Fig. S8b) both give HOM mass fractions of $\sim 75 \%$ on average. The simulation where the vapor pressures of the HOMs are based on results from COSMO-RS gives HOM mass fractions of $\sim 50 \%$ (Fig. S8c) due to the higher vapor pressures of the HOMs. The fractions of total VOC products from MCM in the particle phase (LVOC + SVOC) are $\sim 10 \%$ for the base case and $\sim 20 \%$ for the run using COSMO-RS. The small contribution of SVOCs to the particle growth is one likely reason why the model seems to underestimate the growth of particles larger than $\sim 20 \mathrm{~nm}$ in diameter and thus causes too low concentration of particles with diameter $>50 \mathrm{~nm}$ (Fig. 5). The modeled particle composition can be compared with the few AMS observations that exist from the Pallas field station. According to Kivekäs et al. (2009) the average detectable inorganic aerosol mass fraction (nitrate, ammonia and sulfate) was $23 \%$, and the remaining $77 \%$ was organics for aerosol particles originating from marine air masses during the second Pallas Cloud Experiment conducted between 16 September and 6 October 2005. During the third Pallas Cloud Experiment (21 September to 3 October 2009), when the air masses were originating from Northern Atlantic Ocean and the Arctic, the AMS measurements together with black carbon measurements with a Multi-Angle Absorption Photometer (MAAP) gave an average composition of $47 \%$ organics, $26 \%$ sulfate, $13 \%$ ammonia, $8 \%$ nitrate and $6 \%$ black carbon (Jaatinen et al., 2014). However, during the only strong new particle formation and growth event occurring during this campaign more than $70 \%$ of the particles mass was composed of organics (Fig. 2c in Jaatinen et al., 2014). Because of the generally very low mass concentrations $\left(<1 \mu \mathrm{g} \mathrm{m}^{-3}\right)$ during the second and third Pallas Cloud Experiment no reliable sizeresolved chemical composition could be derived from the AMS measurements. However, Jaatinen et al. (2014) compared the aerosol hygroscopicity parameter, $\kappa$, derived using the non-size-resolved AMS chemical compositions with the size-resolved $\kappa$ derived with an HT-DMA and a CCN counter. According to this closure the AMS $\kappa$ was generally above 0.2 and substantially higher than the $\kappa$ values derived with HT-DMA and a CCN counter. For particles with diameters between 15 and $75 \mathrm{~nm}$ the $\kappa$ values were in the range between 0.05 and 0.08 based on the HT-DMA and CCN counter measurements. Jaatinen et al. (2014) concluded that this was likely because the newly formed particles were mainly composed of organic compounds. In our base-case simulation the secondary aerosol particle mass is also strongly dominated by organic compounds with an average mass fraction of $85 \%$ for the base-case simulation and with the remaining inorganic secondary aerosol mass fraction mainly being composed of sulfate (Fig. 7). Thus, the ratio between the modeled total organic mass and the inorganic secondary aerosol mass (nitrate, ammonia and sulfate) is somewhat larger than reported by Kivekäs et al. (2009) and substantially larger than the average values from Jaatinen et al. (2014). However, both AMS measurement campaigns were performed during the autumn when the BVOC emissions from the boreal forest generally are relatively low, while our modeled cases mainly are from the late spring and summer months when the BVOC emissions generally are higher because of higher temperatures and photosynthetic active radiation (e.g., Schurgers et al., 2009a). Additionally, we have only focused on days with strong new particle formation and consecutive particle growth. Jaatinen et al. (2014) conclude that particular during these days the sub-micron particles are likely mainly composed of secondary organic material. It is likely that the model underestimates the sulfate mass in the accumulation-mode particles because we did not consider aerosol in-cloud processing and heterogeneous sulfate formation by oxidation of $\mathrm{SO}_{2}$ in the cloud droplets. Also water-soluble organic compounds may be involved in heterogeneous reactions leading to additional SOA formation in the accumulation mode (e.g., Topping et al., 2013b). However, it is unlikely that this can explain why the model underestimates $N_{50}$ the day after the NPF events.

Due to the dominance of HOMs, the $\mathrm{O}: \mathrm{C}$ of the modeled SOA are substantially higher (liq-SIM HOM: 0.99; liqNV HOM: 0.98; liq-COSMO HOM: 0.93) compared to reported values from aerosol mass spectrometry of 0.73 for aged low-volatile SOA (Ng et al., 2010)). In a study by 
Zhang et al. (2015) they imply that particle-phase reaction can lower the $\mathrm{O}: \mathrm{C}$ of SOA formed from HOMs $(\mathrm{O}: \mathrm{C}>0.7)$ to ratios they observe in the aerosol mass spectrometer. In our study, particle-phase reactions of HOMs were not modeled explicitly. The reason for the high $\mathrm{O}: \mathrm{C}$ of the HOMs is that the autoxidation and formation of HOMs are relatively rapid processes which are not strongly hindered by the gas-to-particle uptake of intermediate autoxidation products with lower $\mathrm{O}: \mathrm{C}$. Furthermore, in the model the relatively low BVOC concentrations in the atmosphere compared to most laboratory smog-chamber experiments prevent substantial $\mathrm{HOM}$ dimer formation via $\mathrm{RO} 2+\mathrm{RO}_{2}$ reactions. These reactions lead to earlier termination of the autoxidation and formation of HOMs with lower O : C. One possible explanation to the high $\mathrm{O}: \mathrm{C}$ ratio of the modeled SOA compared to atmospheric observations could be the lack of particle-phase reactions involving SVOCs with low O:C in the model, which would allow more SVOCs to partition to the particle phase. This, possibly together with the underestimated SVOC formation rates, can also explain why the model underestimates $N_{50}$ the day after the NPF events (Fig. 5), even though it seems to overestimate the initial growth (Fig. 4).

Tröstl et al. (2016) showed that in order to explain the observed growth rates of particles in the full size range between $\sim 1$ and $30 \mathrm{~nm}$ in diameter, during an $\alpha$-pinene ozonolysis experiment in the CERN CLOUD chamber, they needed to substantially increase the concentrations of SVOCs and LVOCs in their volatility basis set (VBS) model compared to what was observed with a nitrate chemical ionization atmospheric pressure interface time of flight mass spectrometer (nitrate-CI-APi-TOF). The motivation behind this VBS modification is that the nitrate-CI-APi-TOF likely underestimates the concentrations of HOMs in the SVOC and LVOC volatility range. The modeled average volatility distribution of the SOA and the condensable organic compounds in the gas phase at 00:00 UTC is shown in Fig. 8 (see Fig. S9 for additional VBS distributions at 12:00 UTC on day 1, 18:00 UTC on day 1 and 06:00 UTC on day 2). Of the SOA material, $79.1 \%$ originates from HOM monomers (HOM C10), $1.44 \%$ from HOM monomers containing nitrate functional groups $(\mathrm{HOM} \mathrm{NO})_{3}$ ) and $3.90 \%$ of the $\mathrm{SOA}$ is composed of HOM dimers (HOM C20), which increases during nighttime when the NO is depleted. Although the experiments in Tröstl et al. (2016) do not fully represent the conditions in our atmospheric study, the SOA formation is in both cases dominated by ozonolysis and $\mathrm{OH}$ oxidation of monoterpenes. Thus, we think it is relevant to compare our modeled SOA volatility distribution with theirs. The VBS distribution in Fig. 8 is in good agreement with the fitted VBS distribution reported by Tröstl et al. (2016) (extended data, Fig. 5). They report a ELVOC: LVOC: SVOC ratio of $7: 77: 16$. This can be compared to the average ELVOC: LVOC: SVOC ratio of $7.18: 87.2: 5.58$ in Fig. 8. Figure S10 shows volatility distributions derived from the model results from the liq-COSMO HOM scenario.

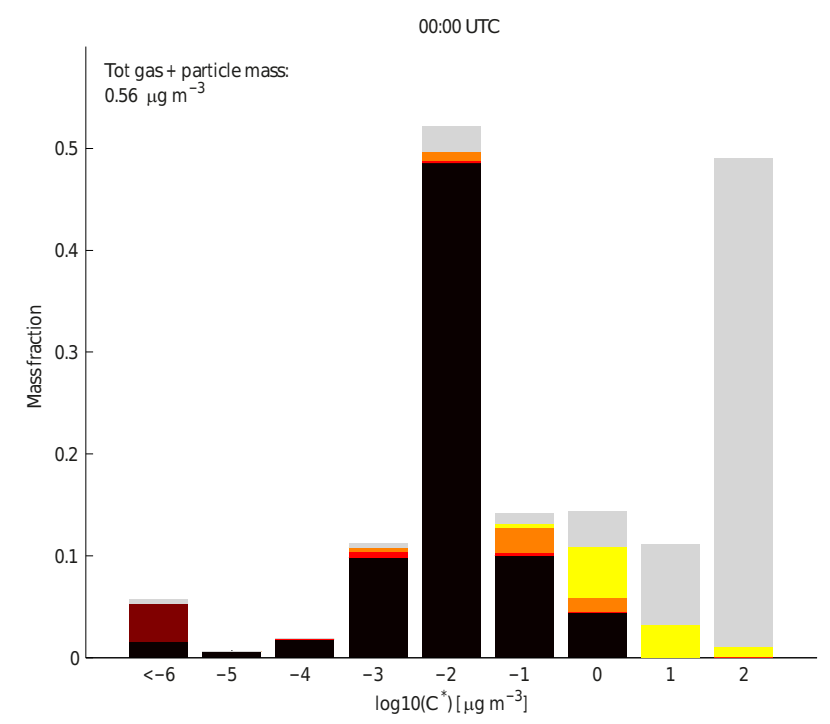

Figure 8. Modeled mean volatility distribution of SOA components at Pallas at 00:00 UTC. The gray bars are the sum of all oxidized organic compounds in the gas phase with $C^{*} \leq 10^{2} \mu \mathrm{g} \mathrm{m}^{-3}$. The mass in each volatility bin is normalized to the total mass (gas and particle phase) of compounds with $C^{*} \leq 1 \mu \mathrm{g} \mathrm{m}^{-3}$. The black, dark red, red, orange and yellow bars are HOM C10, HOM C20, HOM $\mathrm{C} 10-\mathrm{NO}_{3}, \mathrm{MCM}$ LVOC and MCM SVOC, respectively. The particles are assumed to be liquid and the vapor pressures of the HOMs are estimated with SIMPOL with a temperature of $298 \mathrm{~K}$.

We also evaluated the impact of the SOA phase by running the model as the base-case model run but with solid-like SOA particles instead of liquid. The differences between the basecase model runs and these simulations are minor (Fig. S11). One of the reasons for this is that the main fraction of the SOA is formed by condensation of LVOCs (Fig. 8). If a dominating fraction of the SOA instead were SVOCs, the SOA phase state would most likely have a larger impact on the model results (see, e.g., Zaveri et al., 2014). The most notable difference in our model results is that the fraction of nitrate is higher for particle sizes around $500 \mathrm{~nm}$ in diameter when the particles are assumed to be solid. The reason for this is that the solid surface layer, composed of low-volatility HOM SOA, traps the ammonium nitrate in the particle interior. The evaporation of ammonia and nitric acid will therefore be inhibited when the particles are solid as opposed to when they are liquid. The SVOCs from the MCM chemistry are not as much affected by the phase state of the particles as the ammonium nitrate. One likely reason for this is that, as opposed to the ammonium nitrate, the SVOCs are continuously replenished in the gas phase due to the continuous BVOC emissions over the forest. The result from this study implies that in environments with higher ammonia and $\mathrm{NO}_{x}$ emission or during conditions when the SOA formation mainly is driven by condensation of SVOCs, the phase state of the particles could be an important factor to take into consideration. However, 
in the boreal environment of this study, at least the ammonium nitrate formation generally only contributes to a minor fraction of the secondary particle mass formation (e.g., Jaatinen et al., 2014, and Fig. 7) and does not contribute to the growth of the newly formed particles during the NPF events (Fig. S12).

Finally, to test the influence of the nucleation rate on particle growth, a sensitivity test was done where kinetic $\mathrm{H}_{2} \mathrm{SO}_{4}$ nucleation (Eq. 3) was used. On average, the kinetic sulfuric acid nucleation mechanism, as implemented in this work, caused more particles to form but the concentration of larger particles was fairly insensitive to the change in nucleation mechanism (Figs. S13 and S14).

\section{Conclusions}

During recent years the HOM formation from endocyclic monoterpenes has been studied in laboratory and field environments (e.g., Ehn et al., 2014; Jokinen et al., 2015). In this study we evaluated the importance of HOM formation from monoterpene autoxidation in a boreal environment. The modeled HOM formation rate is high enough to give sufficient condensable vapors to explain or even slightly overestimate the growth of the newly formed particles between 1.5 and $\sim 20 \mathrm{~nm}$ in diameter, if most of the formed HOMs are LVOCs or ELVOCs. Between $\sim 20$ and $80 \mathrm{~nm}$ in diameter the model seems to underestimate the particle growth, even if the HOMs were assumed to be nonvolatile. At the same time the model gives a very high $\mathrm{O}: \mathrm{C}$ ratio of nearly 1 for the SOA. Possible explanations to this could be that we did not consider particle-phase oligomerization involving SVOCs in the model or that the model underestimates the SVOC formation rate from BVOCs. With more SVOCs and particle-phase oligomerization, mainly the growth of the larger particles $(>20 \mathrm{~nm}$ in diameter) would increase and the $\mathrm{O}: \mathrm{C}$ decrease. We suggest that future studies should follow up on how heterogeneous reactions involving HOMs and other SVOCs influence the particle number size distribution evolution and the aerosol chemical composition during new particle formation events.

The modeled SOA mass formation was dominated by condensation of HOMs. However, the estimation of the vapor pressures of HOMs is very uncertain. A recent study by Kurtén et al. (2016) suggests that the vapor pressures might be higher than previously thought and that the contribution of HOMs in the particle phase might be due to rapid reactions in the particle phase. We performed a sensitivity test where the vapor pressures of the HOMs were in line with values in Kurtén et al. (2016) and found that the model then seemed to explain the initial growth of the particles better than in the simulation with lower vapor pressures.

The growth of the particles was found to be independent on the phase state of the particles; the phase state might, however, be of importance when the fraction of semi-volatile par- ticulate matter is higher. In these cases, enrichment of lowvolatility organic compounds at the particle surface might act as a protective shield against evaporation of SVOCs, ammonia and nitric acid.

Data availability. Supplementary data are available at https://doi.org/10.1594/PANGAEA.877695 (Öström et al., 2017).

\section{The Supplement related to this article is available online at https://doi.org/10.5194/acp-17-8887-2017-supplement.}

Competing interests. The authors declare that they have no conflict of interest.

Acknowledgements. This work was carried out with the support by Nordic Center of Excellence programs CRAICC (CryosphereAtmosphere Interactions in a Changing Arctic Climate) and eSTICC (eScience tools for investigating Climate Change in Northern High Latitudes), the European Union's Horizon 2020 research and innovation programme under grant agreement no. 654109, the European Research Council (grant 638703-COALA), the Swedish Strategic Research Program MERGE, Modeling the Regional and Global Earth System, the Lund Centre for studies of Carbon Cycle and Climate Interaction (LUCCI), the Swedish Research Council for Environment, Agricultural Sciences and Spatial Planning FORMAS (project no. 2014-1445) and the Academy of Finland Center of Excellence program (project no. 272041).

The authors would like to thank Fredrik Söderberg at the Centre for Environmental and Climate Research at Lund University for providing help to set up the model at the high-performance computing cluster available at the Centre for Scientific and Technical Computing at Lund University (Lunarc) and Finnish Meteorological Institute for providing the measurement data at Pallas.

Edited by: H. Grothe

Reviewed by: two anonymous referees

\section{References}

Ahlström, A., Schurgers, G., Arneth, A., and Smith, B.: Robustness and uncertainty in terrestrial ecosystem carbon response to CMIP5 climate change projections, Environ. Res. Lett., 7, 44008, https://doi.org/10.1088/1748-9326/7/4/044008, 2012.

Arneth, A., Niinemets, Ü., Pressley, S., Bäck, J., Hari, P., Karl, T., Noe, S., Prentice, I. C., Serça, D., Hickler, T., Wolf, A., and Smith, B.: Process-based estimates of terrestrial ecosystem isoprene emissions: incorporating the effects of a direct $\mathrm{CO}_{2}$-isoprene interaction, Atmos. Chem. Phys., 7, 31-53, https://doi.org/10.5194/acp-7-31-2007, 2007. 
Asmi, E., Kivekäs, N., Kerminen, V.-M., Komppula, M., Hyvärinen, A.-P., Hatakka, J., Viisanen, Y., and Lihavainen, H.: Secondary new particle formation in Northern Finland Pallas site between the years 2000 and 2010, Atmos. Chem. Phys., 11, 12959-12972, https://doi.org/10.5194/acp-11-12959-2011, 2011.

Bäck, J., Aalto, J., Henriksson, M., Hakola, H., He, Q., and Boy, M.: Chemodiversity of a Scots pine stand and implications for terpene air concentrations, Biogeosciences, 9, 689-702, https://doi.org/10.5194/bg-9-689-2012, 2012.

Beecken, J., Mellqvist, J., Salo, K., Ekholm, J., Jalkanen, J.-P., Johansson, L., Litvinenko, V., Volodin, K., and Frank-Kamenetsky, D. A.: Emission factors of $\mathrm{SO}_{2}, \mathrm{NO}_{x}$ and particles from ships in Neva Bay from ground-based and helicopter-borne measurements and AIS-based modeling, Atmos. Chem. Phys., 15, 52295241, https://doi.org/10.5194/acp-15-5229-2015, 2015.

Bergström, R., Denier van der Gon, H. A. C., Prévôt, A. S. H., Yttri, K. E., and Simpson, D.: Modelling of organic aerosols over Europe (2002-2007) using a volatility basis set (VBS) framework: application of different assumptions regarding the formation of secondary organic aerosol, Atmos. Chem. Phys., 12, 8499-8527, https://doi.org/10.5194/acp-12-8499-2012, 2012.

Bourtsoukidis, E., Bonn, B., and Noe, S. M.: On-line field measurements of BVOC emissions from Norway spruce (Picea abies) at the hemiboreal SMEAR-Estonia site under autumn conditions, Boreal Environ. Res., 19, 153-167, 2014.

Crounse, J. D., Nielsen, L. B., Jørgensen, S., Kjaergaard, H. G., and Wennberg, P. O.: Autoxidation of Organic Compounds in the Atmosphere, J. Phys. Chem. Lett., 4, 3513-3520, 2013.

Dal Maso, M., Kulmala, M., Riipinen, I., Wagner, R., Hussein, T., Aalto, P. P., and Lehtinen, K. E. J.: Formation and growth of fresh atmospheric aerosols: eight years of aerosol size distribution data from SMEAR II, Hyytiälä, Finland, Boreal Environ. Res., 10, 323-336, 2005.

Damian, V., Sandu, A., Damian, M., Potra, F., and Carmichael, G. R.: The kinetic preprocessor KPP-a software environment for solving chemical kinetics, Comput. Chem. Eng., 26, 1567-1579, https://doi.org/10.1016/S0098-1354(02)00128-X, 2002.

Draxler, R. and Rolph, G. D.: HYSPLIT (HYbrid Single-Particle Lagrangian Integrated Trajectory) Model, NOAA Air Resources Laborotory's (ARL), Silver Spring, MD, available at: http:// ready.arl.noaa.gov/HYSPLIT.php (last access: 1 October 2016), 2013

Eckert, F. and Klamt, A.: Fast Solvent Screening via Quantum Chemistry: COSMO-RS Approach, AIChE J., 48, 369-385, 2002.

Eckert, F. and Klamt, A.: COSMOTherm, Version C3.0, Release 15.01; COSMOlogic GmbH \& Co. KG, Leverkusen, Germany, 2014.

Ehn, M., Thornton, J. A., Kleist, E., Sipilä, M., Junninen, H., Pullinen, I., Springer, M., Rubach, F., Tillmann, R., Lee, B., Lopez-Hilfiker, F., Andres, S., Acir, I.-H., Rissanen, M., Jokinen, T., Schobesberger, S., Kangasluoma, J., Kontkanen, J., Nieminen, T., Kurtén, T., Nielsen, L. B., Jørgensen, S., Kjaergaard, H. G., Canagaratna, M., Dal Maso, M., Berndt, T., Petäjä, T., Wahner, A., Kerminen, V.-M., Kulmala, M., Worsnop, D. R., Wildt, J., and Mentel, T. F.: A large source of lowvolatility secondary organic aerosol, Nature, 506, 476-479, https://doi.org/10.1038/nature13032, 2014.
Farina, S. C., Adams, P. J., and Pandis, S. N.: Modeling global secondary organic aerosol formation and processing with the volatility basis set: Implications for anthropogenic secondary organic aerosol, J. Geophys. Res., 115, D09202, https://doi.org/10.1029/2009JD013046, 2010.

Fountoukis, C., Megaritis, A. G., Skyllakou, K., Charalampidis, P. E., Pilinis, C., Denier van der Gon, H. A. C., Crippa, M., Canonaco, F., Mohr, C., Prévôt, A. S. H., Allan, J. D., Poulain, L., Petäjä, T., Tiitta, P., Carbone, S., Kiendler-Scharr, A., Nemitz, E., O'Dowd, C., Swietlicki, E., and Pandis, S. N.: Organic aerosol concentration and composition over Europe: insights from comparison of regional model predictions with aerosol mass spectrometer factor analysis, Atmos. Chem. Phys., 14, 9061-9076, https://doi.org/10.5194/acp-14-9061-2014, 2014.

Hermansson, E., Roldin, P., Rusanen, A., Mogensen, D., Kivekäs, N., Väänänen, R., Boy, M., and Swietlicki, E.: Biogenic SOA formation through gas-phase oxidation and gas-to-particle partitioning - a comparison between process models of varying complexity, Atmos. Chem. Phys., 14, 11853-11869, https://doi.org/10.5194/acp-14-11853-2014, 2014.

Hickler, T., Vohland, K., Feehan, J., Miller, P. A., Smith, B., Costa, L., Giesecke, T., Fronzek, S., Carter, T. R., Cramer, W., Kühn, I., and Sykes, M. T.: Projecting the future distribution of European potential natural vegetation zones with a generalized, tree species-based dynamic vegetation model, Global Ecol. Biogeogr., 21, 50-63, https://doi.org/10.1111/j.14668238.2010.00613.x, 2012.

Hodzic, A., Jimenez, J. L., Madronich, S., Aiken, A. C., Bessagnet, B., Curci, G., Fast, J., Lamarque, J.-F., Onasch, T. B., Roux, G., Schauer, J. J., Stone, E. A., and Ulbrich, I. M.: Modeling organic aerosols during MILAGRO: importance of biogenic secondary organic aerosols, Atmos. Chem. Phys., 9, 6949-6981, https://doi.org/10.5194/acp-9-6949-2009, 2009.

Inness, A., Baier, F., Benedetti, A., Bouarar, I., Chabrillat, S., Clark, H., Clerbaux, C., Coheur, P., Engelen, R. J., Errera, Q., Flemming, J., George, M., Granier, C., Hadji-Lazaro, J., Huijnen, V., Hurtmans, D., Jones, L., Kaiser, J. W., Kapsomenakis, J., Lefever, K., Leitão, J., Razinger, M., Richter, A., Schultz, M. G., Simmons, A. J., Suttie, M., Stein, O., Thépaut, J.-N., Thouret, V., Vrekoussis, M., Zerefos, C., and the MACC team: The MACC reanalysis: an $8 \mathrm{yr}$ data set of atmospheric composition, Atmos. Chem. Phys., 13, 4073-4109, https://doi.org/10.5194/acp13-4073-2013, 2013.

IPCC: Climate Change 2013: The Physical Science Basis. Contribution of Working Group I to the Fifth Assessment Report of the Intergovernmental Panel on Climate Change, edited by: Stocker, T. F., Qin, D., Plattner, G.-K., Tignor, M., Allen, S. K., Boschung, J., Nauels, A., Xia, Y., Bex, V., and Midgley, P. M., Cambridge University Press, Cambridge, United Kingdom and New York, NY, USA, 1535 pp., 2013.

Jacobson, M. Z.: Fundamentals of Atmospheric Modeling, 2nd Edn., Cambridge University Press, Cambridge, United Kingdom and New York, NY, USA, 2005.

Jenkin, M. E., Saunders, S. M., and Pilling, M. J.: The tropospheric degradation of volatile organic compounds: a protocol for mechanism development, Atmos. Environ., 31, 81-104, https://doi.org/10.1016/S1352-2310(96)00105-7, 1997.

Jericevic, A., Kraljevic, L., Grisogono, B., Fagerli, H., and Vecenaj, Ž.: Parameterization of vertical diffusion and the atmospheric 
boundary layer height determination in the EMEP model, Atmos. Chem. Phys., 10, 341-364, https://doi.org/10.5194/acp-10341-2010, 2010.

Jokinen, T., Berndt, T., Makkonen, R., Kerminen, V.-M., Junninen, H., Paasonen, P., Stratmann, F., Herrmann, H., Guenther, A. B., Worsnop, D. R., Kulmala, M., Ehn, M., and Sipilä, M.: Production of extremely low volatile organic compounds from biogenic emissions: Measured yields and atmospheric implications, P. Natl. Acad. Sci. USA, 112, 7123-7128, https://doi.org/10.1073/pnas.1423977112, 2015.

Jonsson, Å. M., Westerlund, J., and Hallquist, M.: Size-resolved particle emission factors for individual ships, Geophys. Res. Lett., 38, L12809, https://doi.org/10.1029/2011GL047672, 2011.

Kerminen, V.-M., Paramonov, M., Anttila, T., Riipinen, I., Fountoukis, C., Korhonen, H., Asmi, E., Laakso, L., Lihavainen, H., Swietlicki, E., Svenningsson, B., Asmi, A., Pandis, S. N., Kulmala, M., and Petäjä, T.: Cloud condensation nuclei production associated with atmospheric nucleation: a synthesis based on existing literature and new results, Atmos. Chem. Phys., 12, 12037 12059, https://doi.org/10.5194/acp-12-12037-2012, 2012.

Komppula, M., Lihavainen, H., Hatakka, J., and Paatero, J.: Observations of new particle formation and size distributions at two different heights and surroundings in subarctic area in northern Finland, J. Geophys. Res., 108, 4295, https://doi.org/10.1029/2002JD002939, 2003.

Komppula, M., Lihavainen, H., Kerminen, V.-M., Kulmala, M., and Viisanen, Y.: Measurements of cloud droplet activation of aerosol particles at a clean subarctic background site, J. Geophys. Res., 110, D06204, https://doi.org/10.1029/2004JD005200, 2005.

Kristensson, A., Johansson, C., Westerholm, R., Swietlicki, E., Gidhagen, L., Wideqvist, U., and Vesely, V.: Real-world traffic emission factors of gases and particles measured in a road tunnel in Stockholm, Sweden, Atmos. Environ., 38, 657-673, https://doi.org/10.1016/j.atmosenv.2003.10.030, 2004.

Kulmala, M., Hämeri, K., Aalto, P. P., Mäkelä, J. M., Pirjola, L., Douglas Nilsson, E., Buzorius, G., Rannik, Ü., Dal Maso, M., Seidl, W., Hoffmann, T., Janson, R., Hansson, H.-C., Viisanen, Y., Laaksonen, A., and O'Dowd, C. D.: Overview of the international project on biogenic aerosol formation in the boreal forest (BIOFOR), Tellus B, 53, 324-343, https://doi.org/10.3402/tellusb.v53i4.16601, 2001.

Kulmala, M., Kontkanen, J., Junninen, H., Lehtipalo, K., Manninen, H. E., Nieminen, T., Petäjä, T., Sipilä, M., Schobesberger, S., Rantala, P., Franchin, A., Jokinen, T., Jävinen, E., Äijälä, M., Kangasluoma, J., Hakala, J., Aalto, P. P., Paasonen, P., Mikkilä, J., Vanhanen, J., Aalto, J., Hakola, H., Makkonen, U., Ruuskanen, T., Mauldin III, R. L., Duplissy, J., Vehkamäki, H., Bäck, J., Kortelainen, A., Riipinen, I., Kurtén, T., Johnston, M. V., Smith, J. N., Ehn, M., Mentel, T. F., Lehtinen, K. E. J., Laaksonen, A., Kerminen, V.-M., and Worsnop, D. R.: Direct Observations of Atmospheric Aerosol Nucleation, Science, 339, 943-947, 2013.

Kurtén, T., Tiusanen, K., Roldin, P., Rissanen, M., Luy, J.-N., Boy, M., Ehn, M., and Donahue, N.: $\alpha$-Pinene Autoxidation Products May Not Have Extremely Low Saturation Vapor Pressures Despite High O:C Ratios, J. Phys. Chem. A, 120, 2569-2582, https://doi.org/10.1021/acs.jpca.6b02196, 2016.

Lane, T. E., Donahue, N. M., and Pandis, S. N.: Simulating secondary organic aerosol formation using the volatility basisset approach in a chemical transport model, Atmos. Environ.,
42, 7439-7451, https://doi.org/10.1016/j.atmosenv.2008.06.026, 2008.

Langmann, B., Sellegri, K., and Freney, E.: Secondary organic aerosol formation during June 2010 in Central Europe: measurements and modelling studies with a mixed thermodynamic-kinetic approach, Atmos. Chem. Phys., 14, 3831-3842, https://doi.org/10.5194/acp-14-3831-2014, 2014.

Li, J., Cleveland, M., Ziemba, L. D., Griffin, R. J., Barsanti, K. C., Pankow, J. F., and Ying, Q.: Modeling regional secondary organic aerosol using the Master Chemical Mechanism, Atmos. Environ., 102, 52-61, https://doi.org/10.1016/j.atmosenv.2014.11.054, 2015.

Lohila, A., Penttiliä, T., Jortikka, S., Aalto, T., Anttila, P., Asmi, E., Aurela, M., Hatakka, J., Hellén, H., Henttonen, H., Hänninen, P., Kilkki, J., Kyllönen, K., Laurila, T., Lepistö, A., Lihavainen, H., Makkonen, U., Paatero, J., Rask, M., and Sutinen, R.: Preface to the special issue on integrated research of atmosphere, ecosystem and environment at Pallas, Boreal Environ. Res., 20, 431-454, 2015.

Mårtensson, E. M., Nilsson, E. D., de Leeuw, G., Cohen, L. H., and Hansson, H.-C.: Laboratory simulations and parameterization of the primary marine aerosol production, J. Geophys. Res., 108, 4297, https://doi.org/10.1029/2002JD002263, 2003.

Merikanto, J., Spracklen, D. V., Mann, G. W., Pickering, S. J., and Carslaw, K. S.: Impact of nucleation on global CCN, Atmos. Chem. Phys., 9, 8601-8616, https://doi.org/10.5194/acp-9-86012009, 2009.

Murphy, B. N., Donahue, N. M., Fountoukis, C., Dall'Osto, M., O'Dowd, C., Kiendler-Scharr, A., and Pandis, S. N.: Functionalization and fragmentation during ambient organic aerosol aging: application of the 2-D volatility basis set to field studies, Atmos. Chem. Phys., 12, 10797-10816, https://doi.org/10.5194/acp-1210797-2012, 2012.

Nannoolal, Y., Rarey, J., and Ramjugernath, D.: Estimation of pure component properties, Fluid Phase Equilibr., 269, 117-133, https://doi.org/10.1016/j.fluid.2008.04.020, 2008.

Ng, N. L., Canagaratna, M. R., Zhang, Q., Jimenez, J. L., Tian, J., Ulbrich, I. M., Kroll, J. H., Docherty, K. S., Chhabra, P. S., Bahreini, R., Murphy, S. M., Seinfeld, J. H., Hildebrandt, L., Donahue, N. M., DeCarlo, P. F., Lanz, V. A., Prévôt, A. S. H., Dinar, E., Rudich, Y., and Worsnop, D. R.: Organic aerosol components observed in Northern Hemispheric datasets from Aerosol Mass Spectrometry, Atmos. Chem. Phys., 10, 46254641, https://doi.org/10.5194/acp-10-4625-2010, 2010.

O’Dowd, C. D., Facchini, M. C., Cavalli, F., Ceburnis, D., Mircea, M., Decesari, S., Fuzzi, S., Yoon, Y. J., and Putaud, J.-P.: Biogenically driven organic contribution to marine aerosol., Nature, 431, 676-680, https://doi.org/10.1038/nature02959, 2004.

Pankow, J. F.: An absorption model of gas/particle partitioning of organic compounds in the atmosphere, Atmos. Environ., 28, 185-188, https://doi.org/10.1016/1352-2310(94)90093-0, 1994.

Pankow, J. F. and Asher, W. E.: SIMPOL.1: a simple group contribution method for predicting vapor pressures and enthalpies of vaporization of multifunctional organic compounds, Atmos. Chem. Phys., 8, 2773-2796, https://doi.org/10.5194/acp-8-27732008, 2008.

Öström, E., Roldin, P., Schurgers, G., Mishurov, M., Putian, Z., Kivekäs, N., Lihavainen, H., Ehn, M., Rissanen, M. P., Kurtén, T, Boy, M., and Swietlicki, E.: Model data for sim- 
ulation of secondary organic aerosol formation over the boreal forest, link to NetCDF files in zip archive, PANGAEA, https://doi.org/10.1594/PANGAEA.877695, 2017.

Renbaum-Wolff, L., Grayson, J. W., Bateman, A. P., Kuwata, M., Sellier, M., Murray, B. J., Shilling, J. E., Martin, S. T., and Bertram, A. K.: Viscosity of $\alpha$-pinene secondary organic material and implications for particle growth and reactivity, P. Natl. Acad. Sci. USA, 110, 8014-8019, https://doi.org/10.1073/pnas.1219548110, 2013.

Riipinen, I., Pierce, J. R., Donahue, N. M., and Pandis, S. N.: Equilibration time scales of organic aerosol inside thermodenuders?: Evaporation kinetics versus thermodynamics, Atmos. Environ., 44, 597-607, https://doi.org/10.1016/j.atmosenv.2009.11.022, 2010.

Riipinen, I., Pierce, J. R., Yli-Juuti, T., Nieminen, T., Häkkinen, S., Ehn, M., Junninen, H., Lehtipalo, K., Petäjä, T., Slowik, J., Chang, R., Shantz, N. C., Abbatt, J., Leaitch, W. R., Kerminen, V.-M., Worsnop, D. R., Pandis, S. N., Donahue, N. M., and Kulmala, M.: Organic condensation: a vital link connecting aerosol formation to cloud condensation nuclei (CCN) concentrations, Atmos. Chem. Phys., 11, 3865-3878, https://doi.org/10.5194/acp-11-3865-2011, 2011.

Roldin, P., Swietlicki, E., Schurgers, G., Arneth, A., Lehtinen, K. E. J., Boy, M., and Kulmala, M.: Development and evaluation of the aerosol dynamics and gas phase chemistry model ADCHEM, Atmos. Chem. Phys., 11, 5867-5896, https://doi.org/10.5194/acp-11-5867-2011, 2011a.

Roldin, P., Swietlicki, E., Massling, A., Kristensson, A., Löndahl, J., Eriksson, A., Pagels, J., and Gustafsson, S.: Aerosol ageing in an urban plume - implication for climate, Atmos. Chem. Phys., 11, 5897-5915, https://doi.org/10.5194/acp-11-5897-2011, 2011 b.

Roldin, P., Eriksson, A. C., Nordin, E. Z., Hermansson, E., Mogensen, D., Rusanen, A., Boy, M., Swietlicki, E., Svenningsson, B., Zelenyuk, A. and Pagels, J.: Modelling non-equilibrium secondary organic aerosol formation and evaporation with the aerosol dynamics, gas- and particle-phase chemistry kinetic multilayer model ADCHAM, Atmos. Chem. Phys., 14, 7953-7993, https://doi.org/10.5194/acp-14-7953-2014, 2014.

Roldin, P., Liao, L., Mogensen, D., Dal Maso, M., Rusanen, A., Kerminen, V.-M., Mentel, T. F., Wildt, J., Kleist, E., KiendlerScharr, A., Tillmann, R., Ehn, M., Kulmala, M., and Boy, M.: Modelling the contribution of biogenic volatile organic compounds to new particle formation in the Jülich plant atmosphere chamber, Atmos. Chem. Phys., 15, 10777-10798, https://doi.org/10.5194/acp-15-10777-2015, 2015.

Rolph, G. D.: Real-time Environmental Applications and Display sYstem (READY), NOAA Air Resources Laborotory's (ARL), Silver Spring, MD, available at: http://ready.arl.noaa.gov, last access: 1 October 2016.

Saukko, E., Lambe, A. T., Massoli, P., Koop, T., Wright, J. P., Croasdale, D. R., Pedernera, D. A., Onasch, T. B., Laaksonen, A., Davidovits, P., Worsnop, D. R., and Virtanen, A.: Humiditydependent phase state of SOA particles from biogenic and anthropogenic precursors, Atmos. Chem. Phys., 12, 7517-7529, https://doi.org/10.5194/acp-12-7517-2012, 2012.

Saunders, S. M., Jenkin, M. E., Derwent, R. G., and Pilling, M. J.: Protocol for the development of the Master Chemical Mechanism, MCM v3 (Part A): tropospheric degradation of non- aromatic volatile organic compounds, Atmos. Chem. Phys., 3, 161-180, https://doi.org/10.5194/acp-3-161-2003, 2003.

Schurgers, G., Arneth, A., Holzinger, R., and Goldstein, A. H.: Process-based modelling of biogenic monoterpene emissions combining production and release from storage, Atmos. Chem. Phys., 9, 3409-3423, https://doi.org/10.5194/acp-9-3409-2009, 2009a.

Schurgers, G., Hickler, T., Miller, P. A., and Arneth, A.: European emissions of isoprene and monoterpenes from the Last Glacial Maximum to present, Biogeosciences, 6, 2779-2797, https://doi.org/10.5194/bg-6-2779-2009, 2009b.

Scott, C. E., Rap, A., Spracklen, D. V., Forster, P. M., Carslaw, K. S., Mann, G. W., Pringle, K. J., Kivekäs, N., Kulmala, M., Lihavainen, H., and Tunved, P.: The direct and indirect radiative effects of biogenic secondary organic aerosol, Atmos. Chem. Phys., 14, 447-470, https://doi.org/10.5194/acp-14-4472014, 2014.

Scott, C. E., Spracklen, D. V., Pierce, J. R., Riipinen, I., D’Andrea, S. D., Rap, A., Carslaw, K. S., Forster, P. M., Artaxo, P., Kulmala, M., Rizzo, L. V., Swietlicki, E., Mann, G. W., and Pringle, K. J.: Impact of gas-to-particle partitioning approaches on the simulated radiative effects of biogenic secondary organic aerosol, Atmos. Chem. Phys., 15, 12989-13001, https://doi.org/10.5194/acp-15-12989-2015, 2015.

Seinfeld, J. H. and Pandis, S. N.: Atmospheric Chemistry and Physics: from air pollution to climate change, 2nd Edn., John Wiley \& Sonc, Inc, Hoboken, New Jersey, USA, 2006.

Smith, B., Wårlind, D., Arneth, A., Hickler, T., Leadley, P., Siltberg, J., and Zaehle, S.: Implications of incorporating $\mathrm{N}$ cycling and $\mathrm{N}$ limitations on primary production in an individualbased dynamic vegetation model, Biogeosciences, 11, 20272054, https://doi.org/10.5194/bg-11-2027-2014, 2014.

Smolander, S., He, Q., Mogensen, D., Zhou, L., Bäck, J., Ruuskanen, T., Noe, S., Guenther, A., Aaltonen, H., Kulmala, M. and Boy, M.: Comparing three vegetation monoterpene emission models to measured gas concentrations with a model of meteorology, air chemistry and chemical transport, Biogeosciences, 11, 5425-5443, https://doi.org/10.5194/bg-11-5425-2014, 2014.

Spracklen, D. V., Bonn, B., and Carslaw, K. S.: Boreal forests, aerosols and the impacts on clouds and climate, Philos. T. Roy. Soc. A, 366, 4613-4626, https://doi.org/10.1098/rsta.2008.0201, 2008.

Topping, D., Barley, M., and McFiggans, G.: Including phase separation in a unified model to calculate partitioning of vapours to mixed inorganic-organic aerosol particles, Faraday Discuss., 165, 273-288, 2013a.

Topping, D., Connolly, P., and McFiggans, G.: Cloud droplet number enhanced by co-condensation of organic vapours, Nat Geosci. 6, 443-446, https://doi.org/10.1038/ngeo1809, 2013b.

Topping, D., Barley, M., Bane, M. K., Higham, N., Aumont, B., Dingle, N., and McFiggans, G.: UManSysProp v1.0: an online and open-source facility for molecular property prediction and atmospheric aerosol calculations, Geosci. Model Dev., 9, 899914, https://doi.org/10.5194/gmd-9-899-2016, 2016.

Tröstl, J., Chuang, W. K., Gordon, H., Heinritzi, M., Yan, C., Molteni, U., Ahlm, L., Frege, C., Bianchi, F., Wagner, R., Simon, M., Lehtipalo, K., Williamson, C., Craven, J. S., Duplissy, J., Adamov, A., Almeida, J., Bernhammer, A.-K., Breitenlechner, M., Brilke, S., Dias, A., Ehrhart, S., Flagan, R. C., 
Franchin, A., Fuchs, C., Guida, R., Gysel, M., Hansel, A., Hoyle, C. R., Jokinen, T., Junninen, H., Kangasluoma, J., Keskinen, H., Kim, J., Krapf, M., Kürten, A., Laaksonen, A., Lawler, M., Leiminger, M., Mathot, S., Möhler, O., Nieminen, T., Onnela, A., Petäjä, T., Piel, F. M., Miettinen, P., Rissanen, M. P., Rondo, L., Sarnela, N., Schobesberger, S., Sengupta, K., Sipilä, M., Smith, J. N., Steiner, G., Tomè, A., Virtanen, A., Wagner, A. C., Weingartner, E., Wimmer, D., Winkler, P. M., Ye, P., Carslaw, K. S., Curtius, J., Dommen, J., Kirkby, J., Kulmala, M., Riipinen, I., Worsnop, D. R., Donahue, N. M., and Baltensperger, U.: The role of low-volatility organic compounds in initial particle growth in the atmosphere, Nature, 533, 527-531, https://doi.org/10.1038/nature18271, 2016.

Tunved, P., Hansson, H.-C., Kulmala, M., Aalto, P., Viisanen, Y., Karlsson, H., Kristensson, A., Swietlicki, E., Dal Maso, M., Ström, J., and Komppula, M.: One year boundary layer aerosol size distribution data from five nordic background stations, Atmos. Chem. Phys., 3, 2183-2205, https://doi.org/10.5194/acp-32183-2003, 2003.

Tunved, P., Partridge, D. G., and Korhonen, H.: New trajectorydriven aerosol and chemical process model Chemical and Aerosol Lagrangian Model (CALM), Atmos. Chem. Phys., 10, 10161-10185, https://doi.org/10.5194/acp-10-10161-2010, 2010.

Vaden, T. D., Imre, D., Beránek, J., Shrivastava, M., and Zelenyuk, A.: Evaporation kinetics and phase of laboratory and ambient secondary organic aerosol, P. Natl. Acad. Sci. USA, 108, 21902195, https://doi.org/10.1073/pnas.1013391108, 2011.

Virtanen, A., Joutsensaari, J., Koop, T., Kannosto, J., Yli-Pirilä, P., Leskinen, J., Mäkelä, J. M., Holopainen, J. K., Pöschl, U., Kulmala, M., Worsnop, D. R., and Laaksonen, A.: An amorphous solid state of biogenic secondary organic aerosol particles, Nature, 467, 824-827, https://doi.org/10.1038/nature09455, 2010.

Westervelt, D. M., Pierce, J. R., Riipinen, I., Trivitayanurak, W., Hamed, A., Kulmala, M., Laaksonen, A., Decesari, S., and Adams, P. J.: Formation and growth of nucleated particles into cloud condensation nuclei: model-measurement comparison, Atmos. Chem. Phys., 13, 7645-7663, https://doi.org/10.5194/acp13-7645-2013, 2013.
Yu, F.: A secondary organic aerosol formation model considering successive oxidation aging and kinetic condensation of organic compounds: global scale implications, Atmos. Chem. Phys., 11, 1083-1099, https://doi.org/10.5194/acp-11-1083-2011, 2011.

Zaveri, R. A., Easter, R. C., Shilling, J. E., and Seinfeld, J. H.: Modeling kinetic partitioning of secondary organic aerosol and size distribution dynamics: representing effects of volatility, phase state, and particle-phase reaction, Atmos. Chem. Phys., 14, 5153-5181, https://doi.org/10.5194/acp-14-5153-2014, 2014.

Zhang, X., Mcvay, R. C., Huang, D. D., Dalleska, N. F., Aumont, B., Flagan, R. C., and Seinfeld, J. H.: Formation and evolution of molecular products in $\alpha$-pinene secondary organic aerosol, P. Natl. Acad. Sci. USA, 112, 14168-14173, https://doi.org/10.1073/pnas.1517742112, 2015.

Zuend, A., Marcolli, C., Luo, B. P., and Peter, T.: A thermodynamic model of mixed organic-inorganic aerosols to predict activity coefficients, Atmos. Chem. Phys., 8, 4559-4593, https://doi.org/10.5194/acp-8-4559-2008, 2008.

Zuend, A., Marcolli, C., Booth, A. M., Lienhard, D. M., Soonsin, V., Krieger, U. K., Topping, D. O., McFiggans, G., Peter, T., and Seinfeld, J. H.: New and extended parameterization of the thermodynamic model AIOMFAC: calculation of activity coefficients for organic-inorganic mixtures containing carboxyl, hydroxyl, carbonyl, ether, ester, alkenyl, alkyl, and aromatic functional groups, Atmos. Chem. Phys., 11, 9155-9206, https://doi.org/10.5194/acp-11-9155-2011, 2011. 